\title{
Does an overdraft facility influence the customer costs of using a personal current account?
}

Ashton, John; Gregoriou, Andros

\section{International Journal of the Economics of Business}

DOI:

$10.1080 / 13571516.2016 .1222990$

Published: 01/01/2017

Peer reviewed version

Cyswllt i'r cyhoeddiad / Link to publication

Dyfyniad o'r fersiwn a gyhoeddwyd / Citation for published version (APA):

Ashton, J., \& Gregoriou, A. (2017). Does an overdraft facility influence the customer costs of using a personal current account? International Journal of the Economics of Business, 24(1), 1 26. https://doi.org/10.1080/13571516.2016.1222990

\footnotetext{
Hawliau Cyffredinol / General rights

Copyright and moral rights for the publications made accessible in the public portal are retained by the authors and/or other copyright owners and it is a condition of accessing publications that users recognise and abide by the legal requirements associated with these rights.

- Users may download and print one copy of any publication from the public portal for the purpose of private study or research.

- You may not further distribute the material or use it for any profit-making activity or commercial gain

- You may freely distribute the URL identifying the publication in the public portal ?
}

Take down policy

If you believe that this document breaches copyright please contact us providing details, and we will remove access to the work immediately and investigate your claim. 
Does an overdraft facility influence the customer costs of using a personal current account?

JOHN K. ASHTON*

Bangor Business School, Bangor University, Fford College, Bangor, Gwynedd, UK. LL57 2DG

Email: j.ashton@bangor.ac.uk Telephone:+44(0)1248388193

and

ANDROS GREGORIOU

Brighton Business School

Brighton University, Brighton

* corresponding author.

\section{Acknowledgements}

We would like to acknowledge financial assistance from Friends Provident Charitable Foundation, helpful comments provided by Rhys ap Gwilym, Robert Hudson and José Manuel Liñares-Zegarra and research assistance from Nia Williams. The work was developed from report from Friends Provident Charitable Foundation Ashton and Hudson R.S. (2013). All errors remain the responsibility of the authors. 


\title{
Does an overdraft facility influence the customer costs of using a personal current account?
}

\begin{abstract}
This study examines if personal current accounts offering an overdraft facility costs customers' less to use than accounts not offering this service. This analysis uses a UK data set of 222 personal current accounts, recorded monthly between 1995 and 2011 in combination with interest rates from 1,200 instant access deposit accounts offered contemporaneously by the same firms. Our results indicate personal current accounts offering overdraft facilities have higher deposit and payment service costs than accounts not offering this service; a finding robust to varying service attributes. This result is inconsistent with suggestions that overdraft users have been crosssubsidising other personal current account users as widely reported in theoretical and policy literatures. It is concluded that implicit and inertia costs of personal current account use may be more influential than previously reported in the pricing of these accounts.
\end{abstract}

Key words: Checking accounts, Personal current accounts, Contingent charges, Implicit costs, Interest rate setting, Overdrafts.

G21 - Banks; Other Depository Institutions; Micro Finance Institutions; Mortgages 


\section{Introduction}

The pricing of add-on or contingent services provided in addition to a base good has been the focus of much theoretical and policy speculation. This study examines the customer costs associated with providing one such add-on good, bank overdrafts which are offered as an additional service for personal current accounts (also termed checking accounts) ${ }^{\mathrm{i}}$. We examine this question by testing if the explicit and implicit costs of using personal current accounts varies significantly with whether the account offers an overdraft facility or otherwise. Explicit customer costs include packaged fees for accessing the account and implicit costs are defined as the difference in interest rate yields offered on personal current account deposits and yields from instant access deposit accounts offered contemporaneously by the same provider. This assessment, augmented by consideration of a wide range of service attributes, employs a data set of 222 personal current accounts and 1,200 deposit accounts offered monthly between 1995 and 2011 in the UK.

Using a descriptive assessment and regression model, we report providing an overdraft facility is significantly associated with the customer costs of using base services (deposit and payments services) in personal current accounts. The direction of this relationship is not, as a widely predicted, from overdraft services to other personal current account users. Alternatively the presence of an overdraft facility increases the customer costs of using current account base services. This assessment indicates that implicit or inertia costs of personal current account use may be more influential than previously reported in the pricing of these services.

The research question is important to address as academics and policymakers have reported overdraft users may subsidise other personal current account customers. For example Armstrong and Vickers (2012) report 'financially constrained customers pay contingent fees which help fund the free service offered to those in credit - (this) might appear to some as a 
kind of "reverse Robin Hood exercise", (p.479)". These sentiments have also been raised repeatedly by legislators and regulators across the globe. For example within the UK, the House of Commons Treasury Committee (2011, paragraph 80) reported '... so-called free banking has important distributional consequences. A minority of consumers, often those on lower incomes, pay explicit charges associated with overdrafts. This results in high prices and poor outcomes for a sub-set of consumers. Meanwhile, other consumers, often on higher-incomes do not pay explicitly for their current account provision'.

Examining this question in the UK is timely as while a diversity of approaches are used to price personal current accounts internationally, the 'free banking' pricing model, dominant in the UK since the 1980s, is increasingly being used in Ireland, Australia and the USA (see Central Bank of Ireland 2012, Australian Senate 2011, Consumer Financial Protection Bureau 2013). In this payment model, the customer pays for personal current account 'base services' indirectly and compensates the provider directly for overdraft use through contingent fees and additional charges. The indirect costs of using base (deposit and payment services) services include depositing funds in personal current accounts receiving relatively low levels of interest and the payment of merchants or interchange fees by retailers (see Schmiedel et al. 2012). Increasingly these indirect costs for accessing personal current account base services have been augmented by the promotion of accounts with a 'packaged' fee payable for accessing the account.

Regulators and legislators in Australia (Australian Senate 2011), the European Union (European Commission Directorate-General for Competition 2006; Commission of the European Communities 2009), Ireland (Central Bank of Ireland 2012), the United Kingdom (Competition Commission 2008; Office of Fair Trading 2008, 2010a, 2010b, 2011, 2013 [hereafter OFT]; House of Commons Treasury Committee 2011) and the USA (Federal Deposit 
Insurance Corporation 2008; Consumer Financial Protection Bureau 2013) have all reported concerns with the provision and the pricing of personal current accounts and associated overdraft services within a 'free banking' context. While, this international policy discussion has been accompanied by notable theoretical (Armstrong and Vickers 2012), legal (Whittaker 2011) and US empirical contributions (e.g. Fusaro 2008, 2010; Stango and Zinmann 2009a,b, 2014; Fusaro and Ericson 2010), there is a paucity of empirical evidence examining how personal current accounts services are priced in nations where 'free banking' is the dominant pricing model.

This study contributes to this debate by considering if the provision of an overdraft facility in a personal current account affects the customer costs of using such an account. If the assumption that overdraft lending is cross-subsidising other personal current account services is reliable, we would expect the customer costs of using payment and deposit (base) services of personal current accounts offering an overdraft facility to be lower relative to accounts which do not offer such a facility. As this relationship is not observed for the UK personal current market over a 17 year period, this regulatory, policy and theoretical assumption may require further analysis. We suggest inert customers which accumulate large deposits in their personal current accounts may be paying far more for personal current account services than previously acknowledged.

The study is divided into five sections. After this introduction, academic literatures are examined. In the third section the data and empirical design are introduced and the results are discussed in the fourth section. The conclusions and implications of the study are then provided. 


\section{Literature review}

In light of the preceding discussion, any literature review of personal current accounts and overdraft costs could consider a diversity of concerns and for compactness we examine three areas. Initially we review the developing theoretical literatures pertaining to contingent charges and how these have been applied to personal current account markets. Secondly, the empirical work undertaken on the provision of, demands for and the pricing of personal current account services are outlined. Lastly we consider the past regulatory examinations of this market with a focus on UK contributions.

\section{Theoretical literature on contingent charges and current account pricing}

Contingent charges, such as overdraft costs, are applied to goods and services purchased in an aftermarket, in addition to and after a base good or service is obtained through a primary market. While contingent charges provide pricing efficiencies for firms by allocating costs to those customers using additional services, they also present challenges. In particular concerns arise when firms can exercise market power over an aftermarket and levy high contingent charges and fees.

Shapiro (1995) reports four circumstances when market power within aftermarkets develops. Initially, customers may be surprised by firms unexpectedly raising prices in aftermarkets; an outcome leading customers to switch provider when possible. Secondly, if customers are poorly informed and fail to account for the costs of using aftermarkets due to optimism or the costs of comprehending charges, firms can maximise profits from an aftermarket. This may result in firms escalating competitive actions in the primary market to obtain additional aftermarket customers (Bennett 2011). Third, when firms have a limited ability to make credible or binding price and quality commitments at the time of the base good purchase, 
incentives for firms to maximise profits in aftermarkets arise. Lastly, if the firm is able to exclude rivals from aftermarkets, the ability to price discriminate is enhanced.

Concerns have also emerged that firms may also exaggerate customers' decision making biases through contingent charging. This assumption is central to an expanding theoretical literature assessing the market interaction between profit maximising firms and 'boundedly rational', 'myopic', 'naïve' or 'less informed' consumers. This work considers the firms' strategic use of confusing pricing schemes to enhance consumers' decision errors. For example Gabaix and Laibson (2006) indicated circumstances where exploitation of customers' weakness in comprehension and decision making by firms may persist under competitive conditions in the joint pricing of base and add-on goods. Subsequently cross subsidies may flow from profits achieved on add-on goods purchased by less informed customers, to subsidise base goods purchased by all customers. In the presence of myopic customers high rents in aftermarket or add-on good markets persist even in the face of increasing base market competition (Miao 2010).

As financial services markets are characterised by limited consumer comprehension and financial literacy (FSA 2006, Worthington 2007, Agarwal et al 2008) and personal current accounts markets are associated with high switching costs and employ a diversity of pricing formats, this theoretical literature appears apposite for this market. Despite this relevance, links between this market and such theory have been piecemeal, with the notable exception of Armstrong and Vickers (2012). These authors examined the pricing of overdrafts viewing these services to be a tied aftermarket complimentary yet distinct from primary or base personal current account services (deposits and payment services). The model assumes customers are confronted by small print or confusing pricing formats when choosing a personal current account. Diligent customers' which can observe this small print and comprehend pricing 
formats, can take inefficient actions to choose a personal current account with the lowest overall usage costs. Distinctly naïve customers are misled by small print and confusing pricing formats and unnecessarily incur fees. As these naïve customers will be unaware of high overdraft costs, they will choose the lowest cost provider of base personal current account services (deposit and payment services) unaware of the additional or contingent charges for overdraft use.

These differential actions for naïve and diligent customers result in two possible outcomes. If there is a large proportion of naïve customers and the aftermarket prices are high, firms will actively compete in the primary market for personal current accounts and charge more for additional overdraft services. These actions result in overdraft use subsidising the personal current account base services and naïve customers subsidising diligent customers. This outcome raises concerns as to inefficient patterns of pricing being created and the redistribution of costs between customer groups. Alternatively, if there are enough diligent customers or low enough contingent charges then efficient contract terms will develop and no cross-subsidy will emerge. As, recent theoretical contributions (e.g. Grubb 2015) have forwarded alternative explanations for pricing in overdraft markets, such as customer inattention, the assumption of that 'add-on' services are used to subsidise base goods in the personal current account market requires empirical testing.

\section{Empirical literature on pricing current accounts}

To date there is a scarcity of non-US academic work examining personal current accounts and overdraft pricing. In the UK past examinations of the personal current account market have generally addressed concerns other than the costs of account use. These studies have examined topics including the transmission of monetary policy (e.g. Heffernan 2002), the switching of 
current accounts (e.g. Gondat-Larralde and Nier 2006; Morgans 2010) and financial exclusion (e.g. Devlin 2005). A limited number of studies have also considered personal current account pricing in Canada (Seldon and Solmer 1996), the Netherlands (Cunha et al. 2011) and Scandinavia assessing topics including the pricing of transactional and deposit services (Merrigan and Nomandin 1996; Klee 2008; Tin 2008) and the costs of payment services used within current accounts (Humphrey et al. 2003; Guibourg and Segendorff 2007) ${ }^{\text {iii }}$. Within the Australian context, Worthington (2007) examined the distribution and comprehension of current account characteristics and pricing formats.

In the USA the academic literature is more extensive, examining pricing for payment service use, such as the number of cheques written (e.g. Ederington and Skogstad 1977; Mingo 1980; Osborne and Wendel 1981), assessing overdraft demands (Boyd 1976; Bar-Ilan 1990), customer switching (Kiser 2002) and convert pricing (McGovern and Moon 2007). More recently overdraft pricing and use has been examined using in a number of studies using transaction data from individual customers' personal current accounts (e.g. Stango and Zinman 2011a,b, 2014; Fusaro 2008, 2010; Fusaro and Ericson. 2010). These studies support the conjecture that overdraft use is primarily accidental and personal current account customers' could have minimised the payment of additional fees through more prudential financial management. Fusaro (2008) reports distinct categories of overdraft users exist and possess differing abilities to navigate these markets, with some customers very able at minimising the costs of overdraft use. Stango and Zinman (2011a) report that while only $31 \%$ of personal current account customers have had at least one overdraft fee, a further $72 \%$ of customers have been very close to over-drafting behaviours and displayed financial fragility. Similarly, Fusaro (2008) reports that on average one in five customers incur an overdraft each year and over a 10 year period $46.2 \%$ of customers incur overdrafts. 


\section{Regulatory contributions}

The personal current account market has also been the focus of repeated regulatory attention in the UK and internationally. This has resulted in a distinct literature examining overdraft costs and usage, current account pricing and the competitive conditions prevailing in the personal current account and associated overdraft markets. For the UK these inquiries have been influenced by the fragmented and dynamic regulation of this market over the sample period. Deposit or banking elements are currently regulated by the Financial Conduct Authority (FCA) and were regulated by the Financial Services Authority (FSA) during the sample period. The credit element of overdrafts was regulated by the Office of Fair Trading (OFT), the payments system considered by the Payments Council and competition issues addressed the OFT and the Competition Commission throughout the sample period, before being transferred to the Competition and Markets Authority (CMA).

Regulatory reports on the personal current account market have therefore emerged from many sources. This market has been examined as part of wider examinations of UK banking (e.g. HM Treasury 2000, the House of Commons Treasury Committee 2011, Independent Commission on Banking 2011). Reports have also examined specific services provided within personal current accounts including overdrafts (OFT 2008, 2011, 2013, 2014; CMA 2014) and deposit services (FCA 2014b) as well as distinct markets including small business banking (Competition Commission 2002) and Northern Ireland (Competition Commission 2007). Persistent concerns raised in these reports have included limited customer switching, high barriers to entry and complex pricing formats.

Within this array of reports perhaps the most significant intervention was provided by the now defunct Office of Fair Trading (OFT) in its investigation as to the competitive conditions prevailing within the unauthorised overdraft market (OFT 2008, 2011, 2013, Competition and 
Markets Authority 2014). This competition and consumer protection agency reported that the unauthorised overdraft market and the personal current account market were not working well due a lack of transparency and complexity in pricing, which concentrated competition on more visible fees and charges. The 'free banking' pricing model was considered to result in relatively low interest rates for deposits within personal current accounts and overly high levels of interest and fees for overdraft lending. This scenario troubled this regulator as it was assumed the poor, vulnerable and less aware customers were disproportionally incurring overdraft fees. Legal action ensued as to the fairness of unauthorised overdraft charges with a case between the OFT and seven banks leading to rulings that bank overdraft charges are unfair by the High Court and the Appeal Court before eventually being rejected by the Supreme Court in 2009 (see Whittaker 2011).

In 2011 the OFT also announced a further review of competition within and operation of the personal current account market (OFT 2011). This report outlined new standards for firms supplying overdrafts to be prescribed in the Lending Code. Lastly, the OFT (2013) evaluated changes within unsecured overdraft markets arising from past regulatory changes. It was reported the costs of using unauthorised overdraft services and the underlying profitability of these services had fallen by $£ 928 \mathrm{~m}$. This reform process was recently re-examined by the successor to the OFT, the Competition and Markets Authority (2014) which has reported high barriers to entry and inert customers persist in this market.

Regulatory interest in personal current account pricing has also been international in scope with investigations and reforms of personal current account markets undertaken in Canada, Australia, the USA and the European Union. Canada has introduced the right of all customers to have a bank account that can be used for payment services (excepting in cases of suspected or past fraud) and measures to standardise the calculation and disclosure of current account 
fees (Ministry of Justice 2003). In Australia, legislation has been undertaken to outlaw unfair charging structures including penalty charges on current accounts. Regulatory developments in the USA include the introduction of Regulation E (Electronic Fund Transfers) by the Federal Reserve Board (Federal Register 2010) prohibiting financial institutions from charging customers for overdrafts incurred from ATMs and one-time debit card transactions unless consent is obtained or the customer opts to pay such fees. The Commission of the European Communities (2009) has also reported a high variance and lack of clarity in the costs of personal current accounts across the European Union.

\section{Data and Methodology}

To address whether an overdraft facility influences the cost of personal current account use we undertake a descriptive assessment and employ a regression model. The descriptive assessment examines the relationships between the cost of personal current account use, the services received with the accounts and the availability of an overdraft facility or otherwise. The regression model is used to examine statistical significance of the presence or otherwise of an overdraft facility on the costs of personal current account 'base' (deposit and payment services) services in the presence of attributes of personal current accounts.

\section{Assumptions and Concepts}

In order to undertake the assessment three assumptions are made and require explanation. Initially the costs of using deposit and payment services within personal current accounts are defined as base costs. These base costs vary between the personal current accounts as accounts will have varying interest levels offered for current account deposits, distinct packaged fees 
and may levy these fees and pay interest with different frequencies (i.e. monthly, annually etc.). For reasons outlined in the data section, overdraft costs are not directly quantified and the presence or otherwise of an overdraft service is used to reflect the cost or benefit of providing this service.

Second, to accommodate the opacity of charging for personal current accounts, we measure the implicit costs of account use. Implicit costs are those costs of using personal current accounts which are not clearly linked to a form of action and include the relatively low yield received on personal current account deposits relative the yield received on funds deposited in different financial services. While implicit costs are commonly recognised as a major cost to personal current account users (e.g. Stango and Zinman 2009a; Central Bank of Ireland 2011; Independent Commission on Banking 2012) and have been used in other economic contexts (see Fixler 2009) these costs have either been overlooked or quantified relative to the market rate of funds in past assessments of personal current accounts.

In this study we adopt a distinct approach to estimating implicit costs. Specifically we calculate the difference between interest received on personal current account deposits relative to the average interest receivable by depositing the credit balance in an average instant access deposit account offered contemporaneously by the firm providing the personal current account. This enables comparison of the costs of a customer opting to accumulate deposits within their personal current account or choosing to deposit or sweep funds into an average instant access deposit account offered by the same bank. This approach reflects the benefits of automatic transfers between current and deposit accounts advocated in the USA to enhance interest payments and reduce overdraft use by banks (Consumer Financial Protection Bureau 2013). Further this approach provides a measure of customer costs arising due to inattention and inertia (see Anderson et al 2014, Stango and Zinman 2014). 
A third assumption underlying the analysis is that the costs of using base services are determined by how the personal current account is used by a customer. Preferably customer use is defined using personal current account transactions. As this data is not publically available in the UK we consider an alternative method previously used by regulators (e.g. Competition Commission 2008; OFT 2008; Central Bank of Ireland 2011; Independent Commission on Banking 2011). This representative customer approach, creates a hypothetical customer with actions and levels of service use representative of how customers behave on aggregate.

In total three representative customer definitions which use both base and overdraft services are outlined (with costs only recorded for base costs in the analysis). To reduce subjectivity in defining the levels of customer use, we adopt one existing OFT (2008) representative customer classification derived from a prior assessment of personal current account transaction data. We also follow the approach used by the Competition Commission (2008) to define two further representative customers by interviewing senior bankers with a remit for personal current account provision. Interviews were therefore undertaken with four senior representatives from a very large and a small provider of UK personal current account services and led to two more representative customer definitions. These definitions are outlined in Table 1.

\section{INSERT TABLE 1}

\section{Data}

The empirical analysis employs data from Moneyfacts PLC for the retail personal current account market and the instant access deposit market. This data was accessed from paper based magazines and transformed into a useable dataset for this project. The data is comprehensive ${ }^{\mathrm{iv}}$, 
includes personal current accounts with and without packaged fees ${ }^{\mathrm{v}}$, includes basic bank accounts $^{\mathrm{vi}}$ and accounts with and without an overdraft facility. All these accounts provide a deposit facility and offer some payment services (so are defined as personal current accounts rather than deposit account). These accounts are provided primarily by high street banks, yet also by building societies, small banks, foreign banks and other firms including insurers and retailers. For personal current account deposit services we record four different tiers or levels of interest payable for sums deposited including:

i) Equal to and greater than $£ 1$ deposited and less than $£ 500$,

ii) Greater than or equal to $£ 500$ deposited and less than $£ 1,000$,

iii) Greater than or equal to $£ 1,000$ and less than $£ 2,500$, and,

iv) Greater than or equal to $£ 2,500$ and less than $£ 5,000$.

While some personal current accounts offer higher rates of interest for sums greater than $£ 5,000$ deposited this data was not reported by Moneyfacts PLC and was not available for this study. Therefore this assessment is effectively truncated to considering personal current accounts containing $£ 5,000$ in deposits or less. The frequency of interest rate payment is also recorded and used to ensure any calculations undertaken match the frequency employed by the personal current account (i.e. monthly, quarterly and annually). Where a personal current account requires a packaged fee, the fee amount and frequency of fee payment was recorded. Data is also recorded as to how personal current accounts are distributed and what payment services are provided by these accounts. These product characteristics (e.g. account sweeping, cheque book, unlimited direct debits etc.) are not comprehensive due to the availability of data, yet assist in indicating the differential quality of personal current accounts offered to market. We acknowledge that other forms of distribution, payment services and additional services are not included in this assessment. 
While considerable data on overdraft interest rates, buffers, arrangement and usage fees has been obtained for authorised and unauthorised overdrafts, we have been unable to collect a full set of data relating to additional fees for customers using unauthorised overdrafts, such as letter costs, rejected direct debit and cheque costs. As the omission of unauthorised overdraft charges will understate the level of unauthorised overdraft use costs and we do not wish to interpolate data, these values are not included in this assessment.

\section{INSERT TABLE 2}

Using the approach specified above, 'representative' customers are used to calculate the base costs of personal current account use. The Moneyfacts data set is provided monthly over a 17 year period, for 345 current accounts offered by 71 firms, which are owned by 61 parent companies. This data is truncated to only include those personal current accounts for which both personal current account and instant access deposit observations are available and where personal current accounts have been offered for two years or more. The removal of data where matching instant access deposit and personal current accounts observations were unavailable, primarily affects smaller and foreign banks. We have also removed personal current accounts which were only offered briefly. Some accounts may have been offered for purely marketing purposes such as obfuscation (Carlin and Manso 2010) or bait and switch activities (Lazear 1995) and their inclusion could have distorted the analysis. This provides a contiguous data set of 222 products offered by 42 firm and 34 parent firms; in total 16,667 observations within an unbalanced panel of 222 products and 204 months over a 17 year period. The panel is unbalanced as firms have introduced and withdrawn products over the sample period. 
To estimate implicit costs these personal current account observations are matched with the average interest rates available for the instant access deposit accounts provided by the same parent company. The instant access deposit data has 56,909 monthly observations of 1,200 instant access deposit accounts. Descriptive statistics of fees and interest rates used to calculate base costs of current account use and implicit costs of current account use are presented in Table 3.

The unit of observation for the analysis is therefore the cost of using a particular personal current account. This is recorded monthly over the sample period for 222 products for the three representative customers. The decision to use the product rather than the firm level as a unit of observation is informed by the relatively frequent merger and acquisition of personal current account providers over the sample period (see DeYoung et al. 2010). This has resulted in many personal current account products changing ownership yet continuing to operate with the same brand name and product features. The parent firms (ultimate owners) marketing these personal current accounts are listed in Appendix 1.

Table 3 outlines descriptive statistics of the variables employed and indicates why the approach to quantify implicit prices is followed. In the upper panel of the table we report the mean and dispersion of personal current account pricing, product features, forms of distribution and the average interest rates of the instant access deposit accounts. In total, 160 personal current accounts ( $71 \%$ of observations) have and 62 personal current accounts do not have an overdraft facility. Three of the personal current accounts altered the availability of overdraft facilities throughout the sample period. The average duration of a personal current account in the sample is 75 months with a standard deviation of 44 months. Packaged fees are levied on 76 personal current accounts (67\% of observations) with an average fee of $£ 18.31$ per month. The availability of payment services also varies across the data. Overall $24 \%$ of observations have account sweeping, $78 \%$ have a cheque book and $98 \%$ have unlimited direct debits. Further, 
$89 \%$ of personal current account observations are available through branches, $83 \%$ over the telephone and $67 \%$ are available via the internet.

\section{INSERT TABLE 3}

The lower panel reports the construction of implicit costs for the three representative customers. Initially, three sets of interest rate: a) the interest rate of the personal current account deposit service, b) the average interest rate of an instant access deposit account and c) the prevailing base or policy rate are reported. The yield from depositing three levels of funds ( $£ 830, £ 2,000$ and $£ 400$ for representative customers A, B and C) is then calculated using the appropriate interest rate and frequency and is reported as the average annual yield. These yields vary from very low returns on personal current account deposits to higher returns from average instant access deposit accounts and the highest returns from depositing at the base rate. The implicit customer costs of using a personal current account deposit relative to sweeping these funds into an instant access deposit account or depositing these funds at the base rate is then recorded. It is observed that implicit costs are far higher when base rates are used, suggesting the use of base rates may overestimate implicit costs. As access to retail deposits actually offering the base rate is unusual and due to the relatively high implicit costs arising when this rate is used, the level of implicit cost is defined as personal current account deposit yield minus the average instant access deposit yield.

\section{Methods}

The descriptive assessment examines whether a personal current account offering an overdraft facility or otherwise affects the costs of using base services. This question is examined for the three representative customers and accommodating the 'quality' of personal current account services. The first part of this assessment is undertaken overall and for three time periods (1995- 
99, 2000-04 and 2005-11). We then use quartiles denoting relative customer costs to examine personal current accounts which do and do not offer an overdraft facility. If overdrafts, as 'addon' services, do reduce the price of base services, it is expected more personal current account observations which have an overdraft facility will be recorded in the lowest cost quartile. Similarly, a higher percentage of observations of personal current accounts without an overdraft facility would be expected in the highest cost quartile. This assessment is reported in Table 4.

High costs of using base personal current account services may also reflect differences in the quality of these accounts. Therefore we examine if variables denoting 'quality' of personal current accounts and the base costs of using these accounts are associated. This is again undertaken overall and using quartiles denoting relative customer costs. In the quartile analysis we discriminate between higher and lower quality by counting the number of forms of distribution and total number of payment services offered on each personal current account observation. When a personal current account is available through all forms of distribution and offers all the possible payment services it is denoted as having a higher quality. Where a personal current account is offered through a limited number of distribution channels and provides few payment services it is judged to be of a lower quality.

Lastly, we examine whether the firm offering the personal current account may be accruing economies of scale. As the personal current accounts examined are provided by firms with varying involvement in the UK retail banking market just examining asset size of institutions could provide a misleading perspective $\mathrm{e}^{\mathrm{vii}}$. We therefore represent scale of involvement within retail banking markets through examining whether the firm has a national branch network or otherwise, following the classification used by Ashton and Gregoriou (2014) and reported in Appendix 1. The differences in base costs for customers A, B and C for nationally branching 
firms and other institutions are recorded together with the assessment of product quality in Table 5.

The regression 'test' follows the descriptive assessment and is used to determine if the availability of an overdraft facility in the personal current account has an influence on the costs of using accounts' base services. If the availability of an overdraft facility influences the cost of base services then a dummy variable indicating whether the personal current account observation has or does not have an overdraft facility would be expected to be significant. If the presence of an overdraft facility reduces the cost of using base services, then the expected coefficient sign will be negative. If the presence of an overdraft facility is costly for a bank to provide the expected direction of the coefficient would be positive.

The costs of using personal current account base services for the three representative customers are also assumed to be determined by a range of other factors including the wholesale cost of funds, the services offered within the personal current account, product restrictions and how the personal current account is distributed. The panel data model to be estimated is written as:

$$
Y_{i t}=\alpha_{i}+X_{i t} \beta+f_{t}+u_{i t}
$$

where $i(i=1,2, \ldots, n)$ denotes personal current account products, $t(t=1,2, \ldots, T)$ denotes months, $Y_{i t}$ is the $i t^{\text {th }}$ observation of the dependant variable (personal current account base costs for the three representative customers) and $X_{i t}$ is the $i t^{\text {th }}$ observation of the explanatory variables outlined in Table 2. $\beta$ represents the coefficient vector of the explanatory variables, $f_{t}$ represents the time effects in the model and the error term $u_{i t}$ may be written as $u_{i t}=\mu_{i}+v_{i t}$ where $\mu_{i}$ represents the time invariant individual specific effects and $v_{i t}$ denotes the remaining error.

To determine the appropriate estimator for the regression we undertake a number of steps. As financial institutions and their subsequent product decisions are exposed to similar kinds of 
systematic shocks, we test whether cross-company residuals are contemporaneously correlated. By computing the Breusch and Pagan (1980) Lagrange Multiplier (LM) statistic, $\lambda_{L M}$ we test for contemporaneous error correlations using:

$$
\lambda_{L M}=T \sum_{i=2}^{n} \sum_{j=1}^{i-1} r_{i j}^{2}
$$

where $r_{i j}^{2}$ is the squared $i j^{\text {th }}$ correlation coefficient of cross-company residuals. Under the null of no contemporaneous error correlations across the companies, the test statistic is asymptotically $\chi^{2}$ distributed with $\mathrm{N}(\mathrm{N}-1) / 2$ degrees of freedom, where $\mathrm{N}$ denotes the number of firms in the panel. The p-value of the LM test statistic is zero, which rejects the null hypothesis, suggesting that the error series are contemporaneously correlated across all the products for each of the representative customers.

In light of these results commonly used fixed effects panel estimators are not applicable to our econometric analysis because they do not encapsulate the contemporaneous correlation across all the products in our sample. The decision also reflects a growing unease within the econometric literature as to the widespread and potentially inappropriate application of fixed effects estimators (see Vogelsang 2014). Also, panel estimators that capture endogeneity and joint determination of variables such as the Generalized Method of Moments estimator derived by Blundell and Bond (1998) are not relevant to our dataset. This is because a vast majority of our explanatory variables are dummies, which are by definition exogenous explanatory variables. We therefore adopt the Seemingly Unrelated Regression (SUR) econometric methodology in our empirical analysis.

We accept the panel could be considered to be a three dimensional panel consisting of products, firms and time. We control for products in the cross section and for time within the panel. We 
cannot encapsulate the firm effect as well, yet do account for shocks to firms by using the SUR estimator. We could in principle control for firms in the cross section instead of the products but that would limit our analysis to 42 cross sections instead of 222, which would make our empirical estimates significantly weaker. This testing framework therefore examines the dependent variable, the costs of personal current account use for the three representative customers, over 222 products and for 204 time periods.

\section{Results}

\section{The descriptive assessment}

The descriptive assessment is reported in two tables. Table 4 considers the influence of offering an overdraft on the costs of using base personal current account services (upper panel) and differences in customer costs in quartiles (lower panel). The differences between the 'quality' of personal current account services and whether an account provides an overdraft facility or otherwise is provided in Table 5. In the upper panel of this table, the differences between these costs of using base services are indicated for accounts with and without overdraft facilities. In the middle panel the distribution of higher and lower 'quality' personal current accounts are recorded relative to whether the account offers an overdraft facility or otherwise. In the lower panel, the relationship between firms with and without a national branch network and the base costs is recorded.

In Table 4 we observe when a personal current account is offered with an overdraft, the costs of using base services are higher. These differences are significant using $\mathrm{t}$ tests. There is also a higher dispersion of customer costs when personal current accounts have an overdraft rather 
than when not. The assessment of the customer costs using quartiles supports this general finding. For the majority (75\%) of cells, there are relatively more observations from accounts with no overdrafts rather than otherwise in the lowest cost quartile. For the highest cost quartile there are relatively more observations for personal current accounts offering an overdraft facility. We also test if these distributions of observations are independent using a $\chi^{2}$ test; in all cases, independence is rejected.

In Table 5 we examine the differences between the 'quality' of personal current accounts when an account offers an overdraft facility or otherwise. It is reported that more personal current account payment services are observed when an account offers an overdraft. Personal current accounts providing an overdraft facility are also accessible through a greater number of distribution channels be these branch, telephone or over the internet, relative to accounts not offering overdrafts. In all cases the differences between the occurrence of these service attributes and whether the account is offered with and without an overdraft are significant. The quartile assessment of distribution of higher and lower 'quality' personal current accounts bears out this observation and we see the highest quality quartile is overwhelmingly populated by personal current account observations offering overdraft facilities. The hypothesis that this distribution is independent is rejected in all cases using a $\chi^{2}$ test.

Lastly, the relationship between base costs and firms with and without a national branch network is examined. When considering firms with a national branch network relative to other firms, national branching firms offer a higher proportion of personal current accounts with an overdraft ( $73 \%$ to $62 \%)$. It is reported that national branching banks have higher average base costs for all representative customers. We acknowledge this scale influence can be interpreted in different ways. This could indicate economies of scale are not a strong influence in this assessment and this marketplace. Alternatively, the downward pressure on customers costs 
exercised by offering an overdraft could reflect a scale effect affecting this entire market and distorting these results.

Overall, from the descriptive assessment a mixed picture is forwarded. In our discussion of theory, it was predicted a personal current accounts offering an overdraft would be expected to have lower base costs. The findings reported in Table 4 contradict this prediction as a positive relationship between offering an overdraft in a personal current accounts and base costs is reported. This result is further complicated by the existence of personal current accounts with different levels of service quality. We observe that personal current accounts offering an overdraft also provide more product features and are available through more distribution channels. We do not observe evidence supportive of the predictions of the theory.

In Table 6 we report the regression results. The coefficient for a personal current account offered with overdraft services is statistically significant at the $5 \%$ level for all representative customers. The direction of the relationship is positive indicating providing an overdraft facility adds rather than reduces the costs of using base services. The regression model also indicates other factors have a statistically significant influence on the costs of using personal current account base services. The method of distributing current accounts positively influences the costs of using base services with statistically significant and positive coefficient values for all branch and telephone variables, yet not for internet distribution. The provision of payment services such as account sweeping, cheque books and unlimited direct debits also has a positive and significant influence on the costs of using base services. The influence of the base rate on the cost of using base current account services is statistically significant for two of the three representative customers and negative in all cases. Lastly, the fixed and time effects are significant, suggesting that the product and time-specific shocks differ significantly across the accounts in our sample justifying the use of the panel. 


\section{INSERT TABLES 5, 4, and 6}

\section{Conclusions}

Despite the theoretical and policy importance of contingent charges, empirical examination of the operation and level of these pricing techniques is limited. Perhaps reflecting this lack of empirical investigation, the distribution of customer costs arising from contingent charges has become an issue of public, political and policy concern in some markets and particularly in the provision of personal current accounts and overdraft services. In this market, policy makers, parliamentarians, regulators and theorists have all reported the provision of overdraft lending in a 'free banking' system can lead to a cross-subsidy of all personal current account users from customers opting to use overdraft services. This study empirically examines an aspect of this prediction by testing whether offering an overdraft facility or otherwise is associated with higher or lower costs of using personal current account base services.

The descriptive assessment reports the customer costs of using personal current accounts with an overdraft facility are higher rather than lower. This relationship is complicated by the 'quality' of the personal current account. We therefore undertake a regression assessment of what factors influence the base costs of customer use of personal current accounts. It is reported that having an overdraft is positively associated with the customer costs of using personal current accounts. Many other factors also have a positive influence on current account costs including variables used to represent product quality and distribution. These results do not concur with theoretical predictions that overdrafts, as an overpriced 'add-on' service are predicted to reduce the costs of personal current account base services. Alternatively the 
provision of personal current account services appear to be financed as much by implicit costs arising from inattentive customers allowing large deposits to accumulate in their accounts.

Personal current accounts are used by $95 \%$ of the Australian (ANZ 2011) and 90\% of the UK population (OFT 2008); indeed across the European Union the ubiquity of these services is demonstrated by a customer base greater than that using telephone services, both mobile and fixed line, or even a gas supply (Commission of the European Communities 2009) ${ }^{\text {viii }}$. These markets also contribute a significant proportion of bank revenue; in the case of the UK there were some 65 million active personal current accounts generating revenues of $£ 8.1$ billion for their providers in 2013 (Competition and Markets Authority 2014). When a market is this economically and socially important, clarity and comprehension as to how customer costs are incurred and the efficiency of pricing is essential. Central to on-going public debates surrounding personal current accounts is the assumed subsidy being paid by overdraft users to other customers which do not use these services. This view is associated with the high levels and costs of overdraft lending internationally and the disproportionate use of overdraft services by the inattentive, vulnerable (Financial Conduct Authority 2014a) and the poor ${ }^{\mathrm{ix}}$. Despite the prevalence of this assumption, it is not universally agreed that overdraft users are the sole source of any subsidies; these could also be related to payment service usage or customer inertia (Mullineux 2009).

Much of the policy discussion about this market reflects concerns with the substantial levels of overdraft borrowing observed in many nations, the less 'visible' nature of this borrowing to many inattentive and less affluent users (see Financial Conduct Authority 2014a) and the often complex and potentially confusing format of overdraft pricing. Policy developed internationally to address these concerns has focused on the timeliness and clarity of information and empowering customers to opt into or from overdraft provision. For example, 
in the UK the Lending Code $(2011)^{\mathrm{x}}$ has included an expectation personal current account providers will inform customers when they are about to enter into an unauthorised overdraft and provide the ability for customers to actively opt out of unauthorised overdrafts. Regulatory developments in the USA include the introduction of Regulation E (Electronic Fund Transfers) by the Federal Reserve Board (Federal Register 2010) prohibiting financial institutions from charging customers for overdrafts incurred from ATM and one-time debit card transactions unless consent is obtained or the customer opts to pay such fees.

While such ongoing policy efforts to enhance customer information and choice are welcome, we suggest these should be accompanied by measures to reduce the implicit and inertia costs of personal current account use. Specifically, the default enrolment of customers into systems of automatic redirection or sweeping of funds to and from deposit accounts will lessen implicit costs and minimise overdraft charges. Lastly, further research of pricing formats is required. In this study we observe that the implicit costs of deposit use, the least visible personal current account costs appears to be substantial. These concerns with the pricing of less visible fees, charges and benefits, previously raised by regulators (e.g. OFT 2008, 2011, 2013) and within theory (e.g. Grubb 2015, Piccione and Spiegler 2012) is clearly an important area for further investigation. 


\section{References}

Agarwal, Sumit, Driscoll, John. C., Gabaix, Xavier, and David Laibson, 2009. "The Age of Reason: Financial Decision over the Life Cycle and Implications for Regulation." Brookings Papers on Economic Activity Fall: 51-117.

Anderson, Robert, John. K. Ashton, and Robert Hudson, 2014. "The Influence of Product Age on Pricing Decisions: An Examination of Bank Deposit Interest Rate Setting." Journal of International Financial Markets, Institutions and Money 31 (8): 216-230.

ANZ 2011. Adult Financial Literacy in Australia. Full report on the results from the 2011 ANZ survey, December. http://www.financialliteracy.gov.au/research.

Armstrong, Mark and John. Vickers, 2012. "Consumer Protection and Contingent Charges." Journal of Economic Literature 50 (2): 477-493.

Ashton, John. K and Andros Gregoriou, 2014. "The Influence of Banking Centralisation on Depositors: Regional Heterogenieties in the Transmission of Monetary Policy." Regional Studies 48 (9): 1467-1482.

Ashton, J.K. and Hudson R.S. 2013. What does Free Banking Cost? An assessment of the costs of using UK personal current accounts, Friends Provident Foundation.

Bar-Ilan, Avner 1990. "Overdrafts and the Demand for Money." American Economic Review 80 (5): 1201-1216.

Bennett, Mark. 2011. What role does economics have to play in contingent charges regulation? OFT, Stockholm.

Boyd, John. H. 1976. "Household Demand for Checking Account Money." Journal of Monetary Economics 2 (1): 81-98.

Campbell, John. Y., Jackson, Howell. E., Madrian, Brigette. C. and Peter Tufano, 2010. “The Regulation of Consumer Financial Products: An Introductory Essay with Four Case Studies." John F. Kennedy School of Government Faculty Research Working Paper Series, RWP10-040, Harvard University.

Carlin, Bruce. I. and Gustavo Manso, 2010. "Obfuscation, Learning and the Evolution of Investor Sophistication." Review of Financial Studies 24 (3): 754-785.

Central Bank of Ireland, 2012. A review of personal current account charges, Dublin.

Competition Commission, 2008. Northern Ireland Personal Banking, London.

Commission of the European Communities 2009. "On the Follow up in Retail Financial Services to the Consumer Markets Scoreboard, Commission." Staff Working Document, Brussels, SEC 1251 final. 
Consumer Financial Protection Bureau 2013. CFPB Study of Overdraft Programs. A white paper of initial findings, Iowa.

Cunha, M. Ricardo., Bart. M. Lambrecht., and Pawlina. Grzegorz. 2011.’Household Liquidity and Incremental Financing Decisions: Theory and Evidence.” Journal of Business, Finance and Accounting 38 (7-8): 1016-1052.

Devlin, James. 2005. "A Detailed Study of Financial Exclusion in the UK." Journal of Consumer Policy 28 (1): 75-108.

DeYoung, Robert, Evanoff, Douglas. D. and Philip Molyneux. 2009. "Mergers and Acquisitions of Financial Institutions: A Review of the Post-2000 Literature." Journal of Financial Services Research, 36 (2-3): 87-110.

Ederington, Louis. H. and Samuel. L. Skogstad, 1977. "Measurement of Banking Competition and Geographical Markets: The Market for Checking Accounts." Journal of Money, Banking and Credit 9 (3): 469-482.

European Commission Directorate-General for Competition, 2006. Interim Report II Current Accounts and Related Services. Sector Inquiry under Article 17, Regulation 1/2003, Brussels.

Federal Deposit Insurance Corporation, 2008. FDIC Study of Bank Overdraft Programs, Washington.

Federal Register, 2010. Proposed Rules, 75(39): 9120-9125.

Financial Conduct Authority, 2014a. Consumer credit and consumers in vulnerable circumstances, London.

Financial Conduct Authority, 2014b. Cash savings market study: interim report, MS14/2, London.

Financial Services Authority, 2006. Financial Capability in the UK: Establishing a Baseline, London.

Fixler, Dennis 2009, "Incorporating Financial Services in a Consumer Price Index." in Price Index Concepts and Measurement, eds. W. Erwin Diewert, John S. Greenlees, and Charles R. Hulten, University of Chicago Press: Chicago, December (ISBN 0-226-14855-6).

Fusaro, Marc. A. and Richard. E. Ericson. 2010. "The Welfare Economics of 'Bounce Protection’ Programs.” Journal of Consumer Policy 3 (1): 55-73.

Fusaro, Marc. A. 2008. "Hidden Consumer Loans: An Analysis of Implicit Interest Rates on Bounced Checks;” Journal of Family and Economic Issues 29 (2): 251-363.

Fusaro, Marc. 2010. “Are Bounced Check Loans Really Loans? Theory, Evidence, and Policy." Quarterly Review of Economics and Finance 50 (4): 492-500. 
Gabaix, Xavier and David Laibson. 2006. "Shrouded Attributes, Consumer Myopia, and Information Suppression in Competitive Markets." The Quarterly Journal of Economics, 121 (2): 505-540.

Gerdes, Geoffrey. R. 2008. "Recent Payment Trends in the United States." Federal Reserve Bulletin October: A75-106.

Gondat-Larralde, Céline. and Nier. Erlend. 2006. "Switching costs in the market for personal current accounts: some evidence for the United Kingdom." Bank of England Working Paper (292) Bank of England.

Guibourg, Gabriela and Björn Segendorff. 2007. "A note on the price- and cost structure of retail payment services in the Swedish banking sector." Journal of Banking and Finance 31 (9): 2817-2827.

Heffernan, Shelagh. A. 2002. "How do UK financial institutions really price their banking products?." Journal of Banking and Finance 26 (10): 1997-2016.

House of Commons Treasury Committee, 2010. Competition and choice in the banking sector, London.

Humphrey, David., Magnus. Willesson., Ted. Lindblom., and Goran Bergendahl, 2003. "What does it cost to make a payment." Review of Network Economics 2 (2): 159-174.

Independent Commission on Banking (2011). Final Report, London.

Kiser, Elizabeth. L. 2002. "Predicting Household Switching Behaviour and Switching Costs at Depository Institutions." Review of Industrial Organization 20 (4): 349-365.

Klee, Elizabeth. 2008. "How people pay: Evidence from grocery store data." Journal of Monetary Economics 55 (3): 526-541.

Lazear, Edward. P. 1995. "Bait and Switch.” Journal of Political Economy 103 (4): 813-830.

McGovern, Gail. and Youngme Moon. 2007. "Companies and the Customers which Hate Them." Harvard Business Review 85 (June): 78-84.

Merrigan, Philip. and Michel Normandin. 1996. "Precautionary Saving Motives: An assessment from UK Time Series of Cross-Sections.” Economic Journal 106 (438): 11931208.

Miao, Chun-Hui. 2010. "Consumer myopia, standardization and aftermarket monopolization." European Economic Review 54 (7): 931-946.

Milne, Alister. 2006. "What is in it for us? Network effects and bank payment innovation." Journal of Banking and Finance 30 (6): 1613-1630. 
Mingo, John. J. 1980. “The Microeconomics of Deposit Rate Ceilings: Inferences for NOW accounts and Interest on Checking Accounts." Journal of Banking and Finance 4 (4): 387 395 .

Morgans, Oliver. 2010. Stick or Twist. An Analysis of consumer behaviour in the personal current account market, Consumer Focus, London.

Mullineux, Andrew. 2009. "The regulation of British retail banking utilities." Journal of Financial Regulation and Compliance 17 (4): 453-466.

Office of Fair Trading 2008. Personal Current Accounts in the UK. An OFT Market Study. London

Office of Fair Trading 2010a. Personal Current Accounts in the UK. Progress update. London

Office of Fair Trading 2010b. Personal Current Accounts in the UK. Unarranged overdrafts. London

Office of Fair Trading 2011. Personal Current Accounts in the UK. OFT1319. London

Office of Fair Trading 2013. Evaluating the impact of the 2008 OFT market study and UTCCR test case into personal current accounts. OFT1005eval, London.

Osborne, D. K. and Jeanne Wendel 1981. "A Note on Concentration and Checking Account Prices.” Journal of Finance 36 (1): 181-186

Parrish, Leslie and Josh Frank, 2011. "An analysis of bank overdraft fees: Pricing, market structure and regulation." Journal of Economic Issues 45 (3): 353-361.

Piccione, Michele and Ren. Spiegler, 2012. "Price Competition under Limited Comparability." Quarterly Journal of Economics 127 (1): 97-135.

Rich, Nicole. 2004. Unfair Fees: A Report into Penalty Fees Charged by Australian Banks, Consumer Law Centre Victoria Ltd, Victoria.

Schmiedel, Heiko., Kostova, Gergana and Wiebe Ruttenberg, 2012. "The Social and Private Costs of Retail Payment Instruments. A European Perspective." European Central Bank Occasional Working Paper, 137, Frankfurt am Main.

Schuh, Scott., Shy, Oz and Joanna Stavins. 2010. "Who Gains and Who Loses from Credit Card Payments? Theory and Calibrations." Federal Reserve Bank of Boston Public Policy Discussion Papers No. 10-03.

Seldon, Zena. A. and Audrey. M. Solmer, 1996. "Looking Backwards: A Comparison of Canadian and American Checking Account Service Fees." North American Journal of Economics 7 (2): 217-230.

Senate Economics References Committee 2011. Competition within the Australian Banking Sector, Canberra. 
Shapiro, Carl. 1995. "Aftermarkets and Consumer Welfare: Making Sense of Kodak.” Antitrust Law Journal 63 (2): 483-511.

Stango, Victor and Jonathan Zinmann. 2009a. "Exponential Growth Bias and Household Finance.” Journal of Finance 64 (6): 2807-2849.

Stango, Victor and Jonathan Zinmann. 2009b. "What Do Consumers Really Pay on Their Checking and Credit Card Accounts? Explicit, Implicit, and Avoidable Costs." American Economic Review 99 (2): 424-429.

Stango, Victor. and Jonathan Zinmann. 2014. "Limited and Varying Consumer Attention: Evidence from Shocks to the Salience of Bank Overdraft Fees." Review of Financial Studies 27 (4): 990-1030.

Vogelsang, Timothy J (2012) "Heteroskedasticity, autocorrelation, and special correlation robust inference in linear panel models with fixed effects", Journal of Econometrics, 166, pp.303-319

Whittaker, Simon. 2011. "Unfair Contract Terms, Unfair Prices and Bank Charges." The Modern Law Review 74 (1): 106-134.

Worthington, Andrew. C. 2007. "Personal bank account access and awareness: an analysis of the technological and informational constraints of Australian consumers." International Journal of Consumer Studies 31 (5): 443-452. 
Table 1: Representative customers and use of current accounts

\begin{tabular}{c|c|c|c|c|c|c|c|c}
\hline \hline Label & Group & Description & $\begin{array}{c}\text { Credit } \\
\text { balance }\end{array}$ & $\begin{array}{c}\text { Credit } \\
\text { days }\end{array}$ & $\begin{array}{c}\text { AOD } \\
\text { Balance }\end{array}$ & $\begin{array}{c}\text { AOD } \\
\text { Days }\end{array}$ & $\begin{array}{c}\text { UOD } \\
\text { Balance }\end{array}$ & $\begin{array}{c}\text { UOD } \\
\text { Days }\end{array}$ \\
\hline $\begin{array}{c}\text { Typical } \\
\text { customer } \\
\text { with } \\
\text { unauthorised } \\
\text { overdraft }\end{array}$ & $\begin{array}{c}\text { A typical average } \\
\text { credit balance and } \\
\text { an unauthorised } \\
\text { overdraft }\end{array}$ & $£ 830$ & 345 & 0 & 0 & $£ 40$ & 20 \\
\hline $\begin{array}{c}\text { High credit } \\
\text { customer } \\
\text { with } \\
\text { overdraft use }\end{array}$ & $\begin{array}{c}\text { A high credit } \\
\text { customer for all } \\
\text { except 3 weeks a } \\
\text { year when an } \\
\text { authorised } \\
\text { overdraft is used }\end{array}$ & $£ 2,000$ & 344 & $£ 500$ & 21 & 0 & 0 \\
\hline C & $\begin{array}{c}\text { Mn credit for all } \\
\text { customer } \\
\text { with } \\
\text { overdraft use } 3 \text { weeks a } \\
\text { year when an } \\
\text { authorised } \\
\text { overdraft is used }\end{array}$ & $£ 400$ & 344 & $£ 800$ & 21 & 0 & 0 \\
\hline \hline
\end{tabular}

Notes AOD = authorised overdraft; UOD = unauthorised overdraft 
Table 2. The expected relationships between personal current account (PCA) base costs and product features.

\begin{tabular}{l|l}
\hline \hline $\begin{array}{l}\text { Bank or Product } \\
\text { Feature }\end{array}$ & Influence on Personal Current Account Base Costs \\
\hline $\begin{array}{l}\text { Current account } \\
\text { offered with an } \\
\text { overdraft }\end{array}$ & $\begin{array}{l}\text { The direction of the relationship depends on whether offering an overdraft } \\
\text { positively or negatively influences the customer' costs of using current } \\
\text { accounts. }\end{array}$ \\
\hline $\begin{array}{l}\text { Average wholesale } \\
\text { cost of funds }\end{array}$ & $\begin{array}{l}\text { The average base or policy rate issued by the Bank of England for the month } \\
\text { considered. If the market is linked to the cost of funds then a significant } \\
\text { positive influence is expected. }\end{array}$ \\
\hline Account sweeping & $\begin{array}{l}\text { If customers have a facility to automatically sweep excess current account } \\
\text { funds to another financial account (such as a deposit account), the size of } \\
\text { current deposits will be curtailed. This will therefore be costly for the bank } \\
\text { and have an expected positive influence on the base costs. }\end{array}$ \\
\hline $\begin{array}{l}\text { Cheque book } \\
\text { Unlimited direct } \\
\text { debit }\end{array}$ & $\begin{array}{l}\text { The ability to use cheques is additional convenience for customers, yet costly } \\
\text { to provide. Therefore a positive relationship is expected. }\end{array}$ \\
$\begin{array}{l}\text { This indicates if there are no restrictions on the use of the direct debit system } \\
\text { through the UK BACS payment system. This is expected to exert a positive } \\
\text { influence on base costs. }\end{array}$ \\
$\begin{array}{l}\text { Distribution } \\
\text { PCA branches, } \\
\text { internet } \\
\text { telephone }\end{array}$ & $\begin{array}{l}\text { The use of one or a combination of distribution channels are expected to have } \\
\text { differing influences on base costs depending on their costs to provide. } \\
\text { Branches are widely viewed to be the highest cost and internet provision the } \\
\text { lowest cost forms of distribution. }\end{array}$ \\
\hline $\begin{array}{l}\text { Minimum credit } \\
\text { balance. }\end{array}$ & $\begin{array}{l}\text { If the current account requires customers to pay their primary income into } \\
\text { this account. This requirement is expected to have a negative influence on } \\
\text { base costs as it will be associated with a higher use of the deposit function, } \\
\text { yet also may add to the costs of payment services. }\end{array}$ \\
\hline \hline
\end{tabular}


Table 3: Descriptive Statistics for Personal Current Accounts (PCA).

\begin{tabular}{|c|c|c|c|c|c|c|c|c|}
\hline \multirow{3}{*}{\multicolumn{2}{|c|}{ Sample features }} & \multirow{2}{*}{\multicolumn{3}{|c|}{ PCA Offered with Overdraft Services (\%) }} & \multirow{2}{*}{$\begin{array}{l}\text { Mean } \\
71.0\end{array}$} & \multirow{2}{*}{$\begin{array}{c}\text { Std. Dev. } \\
45.4\end{array}$} & \multirow{2}{*}{$\begin{array}{c}\text { Min. } \\
0\end{array}$} & \multirow{2}{*}{$\begin{array}{c}\text { Max. } \\
1\end{array}$} \\
\hline & & & & & & & & \\
\hline & & \multicolumn{3}{|c|}{ PCA Product Tenure (months) } & 101.23 & 50.90 & 24.00 & 204.00 \\
\hline \multirow{6}{*}{\multicolumn{2}{|c|}{$\begin{array}{l}\text { Personal current } \\
\text { account (PCA) } \\
\text { pricing }\end{array}$}} & \multicolumn{3}{|c|}{ Interest rate $£ 1$ deposited (\%) } & 0.66 & 1.31 & 0.00 & 9.57 \\
\hline & & \multicolumn{3}{|c|}{ Interest rate $£ 500$ deposited (\%) } & 0.68 & 1.33 & 0.00 & 9.57 \\
\hline & & \multicolumn{3}{|c|}{ Interest rate $£ 1000$ deposited (\%) } & 0.77 & 1.39 & 0.00 & 9.57 \\
\hline & & \multicolumn{3}{|c|}{ Interest rate frequency (p.a.) } & 6.82 & 5.07 & 1.00 & 12.00 \\
\hline & & \multicolumn{3}{|c|}{ Fee $(£)$} & 5.01 & 17.17 & 0.00 & 195.00 \\
\hline & & \multicolumn{3}{|c|}{ Fee frequency (p.a.) } & 2.98 & 5.14 & 0.00 & 12.00 \\
\hline \multirow{4}{*}{\multicolumn{2}{|c|}{ Product features }} & \multicolumn{3}{|c|}{ Account sweeping (\%) } & 24.5 & 43.0 & 0.00 & 1.00 \\
\hline & & \multicolumn{3}{|c|}{ Cheque book (\%) } & 78.4 & 41.2 & 0.00 & 1.00 \\
\hline & & \multicolumn{3}{|c|}{ Unlimited direct debits (\%) } & 95.0 & 22.8 & 0.00 & 1.00 \\
\hline & & \multicolumn{3}{|c|}{ Minimum credit balance (£) } & 101.17 & 547.92 & 0.00 & 5000.0 \\
\hline \multirow{3}{*}{\multicolumn{2}{|c|}{ Distribution (\%) }} & \multicolumn{3}{|c|}{ Branch } & 89.0 & 31.3 & 0.00 & 1.00 \\
\hline & & \multicolumn{3}{|c|}{ Telephone } & 83.4 & 37.2 & 0.00 & 1.00 \\
\hline & & \multicolumn{3}{|c|}{ Internet } & 67.1 & 47.0 & 0.00 & 1.00 \\
\hline \multirow{3}{*}{\multicolumn{2}{|c|}{$\begin{array}{l}\text { Instant Access } \\
\text { Deposit Interest } \\
\text { Rates }(\%) \\
\end{array}$}} & \multirow{3}{*}{\multicolumn{3}{|c|}{$\begin{array}{c}£ 500 \text { deposited } \\
£ 1000 \text { deposited } \\
£ 2500 \text { deposited }\end{array}$}} & 2.22 & 1.23 & 0.03 & 5.75 \\
\hline & & & & & 2.30 & 1.26 & 0.03 & 5.75 \\
\hline & & & & & 2.47 & 1.27 & 0.03 & 5.75 \\
\hline Customer & \multicolumn{2}{|c|}{ Annual Yields } & Mean & $\begin{array}{l}\text { Std. } \\
\text { Dev. }\end{array}$ & \multicolumn{2}{|c|}{$\begin{array}{l}\text { Annual measures } \\
\text { of implicit cost } \\
\text { (without fees) }\end{array}$} & Mean & $\begin{array}{l}\text { Std. } \\
\text { Dev. }\end{array}$ \\
\hline A & \multirow{3}{*}{\multicolumn{2}{|c|}{ PCA deposit rate $(\mathfrak{E})$}} & 5.44 & 10.65 & \multirow{4}{*}{\multicolumn{2}{|c|}{$\begin{array}{l}\text { PCA deposit cost } \\
\text { relative to instant } \\
\text { access deposit }(\mathfrak{f})\end{array}$}} & 12.24 & 12.94 \\
\hline B & & & 14.80 & 26.81 & & & 29.1 & 31.5 \\
\hline $\mathrm{C}$ & & & 2.50 & 5.06 & & & & \\
\hline$\overline{\mathrm{A}}$ & \multirow{3}{*}{\multicolumn{2}{|c|}{$\begin{array}{l}\text { Instant access deposit } \\
\text { rate }(\mathfrak{£})\end{array}$}} & 17.68 & 9.88 & & & 5.12 & 6.06 \\
\hline $\mathrm{B}$ & & & 43.90 & 24.20 & & & & 1018 \\
\hline $\mathrm{C}$ & & & 7.62 & 4.90 & PCA de & & 27.8 & 19.18 \\
\hline$\overline{\mathrm{A}}$ & & & 33.24 & 17.05 & relativ & to base & 65.05 & 46.26 \\
\hline $\mathrm{B}$ & & Base rate $(£)$ & 79.86 & 40.96 & & & & \\
\hline $\mathrm{C}$ & & & 15.97 & 8.19 & & & 13.47 & 9.27 \\
\hline
\end{tabular}


Table 4: The influence of offering an overdraft facility on the base costs of using current accounts.

\begin{tabular}{|c|c|c|c|c|c|c|c|}
\hline & & & ustomer & Mean & Std. Dev. & Min. & Max. \\
\hline \multirow{3}{*}{\multicolumn{3}{|c|}{ All current accounts }} & $\mathrm{A}$ & $£ 46.406$ & $£ 69.246$ & $-£ 54.58$ & $£ 720.39$ \\
\hline & & & $\mathrm{B}$ & $£ 63.265$ & $£ 72.158$ & $-£ 125.52$ & $£ 720.94$ \\
\hline & & & $\mathrm{C}$ & $£ 39.286$ & $£ 69.597$ & $-£ 25.63$ & $£ 720.19$ \\
\hline \multirow{3}{*}{\multicolumn{3}{|c|}{$\begin{array}{c}\text { Current accounts offering } \\
\text { overdrafts }\end{array}$}} & $\mathrm{A}$ & $£ 57.577$ & $£ 71.938$ & $-£ 41.77$ & $£ 343.71$ \\
\hline & & & $\mathrm{B}$ & $£ 74.103$ & $£ 75.010$ & $-£ 100.35$ & $£ 405.01$ \\
\hline & & & $\mathrm{C}$ & $£ 50.871$ & $£ 72.235$ & $-£ 19.92$ & $£ 321.00$ \\
\hline \multirow{3}{*}{\multicolumn{3}{|c|}{$\begin{array}{l}\text { Current accounts not } \\
\text { offering overdrafts }\end{array}$}} & A & $£ 22.64$ & $£ 58.15$ & $-£ 54.58$ & $£ 720.39$ \\
\hline & & & $\mathrm{B}$ & $£ 40.59$ & $£ 62.71$ & $-£ 125.52$ & $£ 720.94$ \\
\hline & & & $\mathrm{C}$ & $£ 14.84$ & $£ 57.99$ & $-£ 25.63$ & $£ 720.19$ \\
\hline \multicolumn{4}{|c|}{$\begin{array}{l}\text { Differences between accounts } \\
\text { offering and not offering overdrafts }\end{array}$} & Customer A & \multicolumn{2}{|c|}{ Customer B } & stomer C \\
\hline \multicolumn{4}{|l|}{$\mathrm{t}$ tests } & $25.87 * *(0.0$ & \multicolumn{2}{|c|}{$22.88 * *(0.00)$} & $5 * *(0.00)$ \\
\hline & & \multicolumn{2}{|c|}{ Customer A } & \multicolumn{2}{|c|}{ Customer B } & \multicolumn{2}{|c|}{ Customer C } \\
\hline \multicolumn{2}{|c|}{$\begin{array}{l}\text { Quartiles of } \\
\text { base costs }\end{array}$} & $\begin{array}{c}\text { With } \\
\text { Overdraft } \\
\text { Facility }\end{array}$ & $\begin{array}{c}\text { No } \\
\text { Overdraft }\end{array}$ & $\begin{array}{c}\text { With } \\
\text { Overdraft } \\
\text { Facility }\end{array}$ & $\begin{array}{c}\text { No } \\
\text { Overdraft }\end{array}$ & $\begin{array}{l}\text { With Overdraft } \\
\text { Facility }\end{array}$ & $\begin{array}{l}\text { No } \\
\text { Overdraft }\end{array}$ \\
\hline Highest & 4 & 27.06 & 18.58 & 28.86 & 12.77 & 27.02 & 18.71 \\
\hline \multirow{2}{*}{ Overall } & 3 & 26.09 & 21.49 & 26.16 & 21.24 & 24.87 & 25.41 \\
\hline & 2 & 25.77 & 22.50 & 26.44 & 20.35 & 23.62 & 29.46 \\
\hline \multirow[t]{2}{*}{ Lowest } & 1 & 21.08 & 37.42 & 18.54 & 45.64 & 24.48 & 26.42 \\
\hline & $\chi^{2}$ & $89.70 * *$ & $(0.00)$ & $255.15 * *$ & $(0.00)$ & $25.87 * *$ & $(0.00)$ \\
\hline Highest & 4 & 13.03 & 0.32 & 29.94 & 11.23 & 34.09 & 6.88 \\
\hline \multirow{2}{*}{ 1995-99 } & 3 & 33.22 & 43.35 & 14.24 & 35.13 & 13.60 & 42.25 \\
\hline & 2 & 22.45 & 37.34 & 26.44 & 33.54 & 20.26 & 35.92 \\
\hline \multirow[t]{2}{*}{ Lowest } & 1 & 31.30 & 18.99 & 29.38 & 20.09 & 32.05 & 14.95 \\
\hline & $\chi^{2}$ & $296.33 * *$ & $(0.00)$ & $346.53 * *$ & $(0.00)$ & $735.39 * *$ & $(0.00)$ \\
\hline Highest & 4 & 34.52 & 2.50 & 34.12 & 3.41 & 34.34 & 34.34 \\
\hline \multirow{2}{*}{ 2000-04 } & 3 & 22.82 & 30.18 & 22.96 & 29.82 & 22.91 & 22.91 \\
\hline & 2 & 12.20 & 16.24 & 20.15 & 36.52 & 20.18 & 20.18 \\
\hline \multirow[t]{2}{*}{ Lowest } & 1 & 30.46 & 51.08 & 22.77 & 30.25 & 22.57 & 22.57 \\
\hline & $\chi^{2}$ & $1005.9 * *$ & $(0.00)$ & 945.02 & $(0.00)$ & 981.36 & $(0.00)$ \\
\hline Highest & 4 & 33.52 & 4.19 & 32.71 & 6.18 & 33.57 & 4.09 \\
\hline \multirow{2}{*}{$2005-11$} & 3 & 21.00 & 34.77 & 21.81 & 32.81 & 19.72 & 37.91 \\
\hline & 2 & 22.47 & 31.16 & 23.47 & 28.74 & 22.63 & 30.81 \\
\hline \multirow[t]{2}{*}{ Lowest } & 1 & 23.00 & 29.88 & 22.01 & 32.27 & 24.09 & 27.19 \\
\hline & $\chi^{2}$ & $1610.7 * *$ & $(0.00)$ & 1316.47 & $(0.00)$ & 1753.33 & $(0.00)$ \\
\hline
\end{tabular}


Table 5: Relationship between offering an overdraft facility, current account 'quality' and firm size.

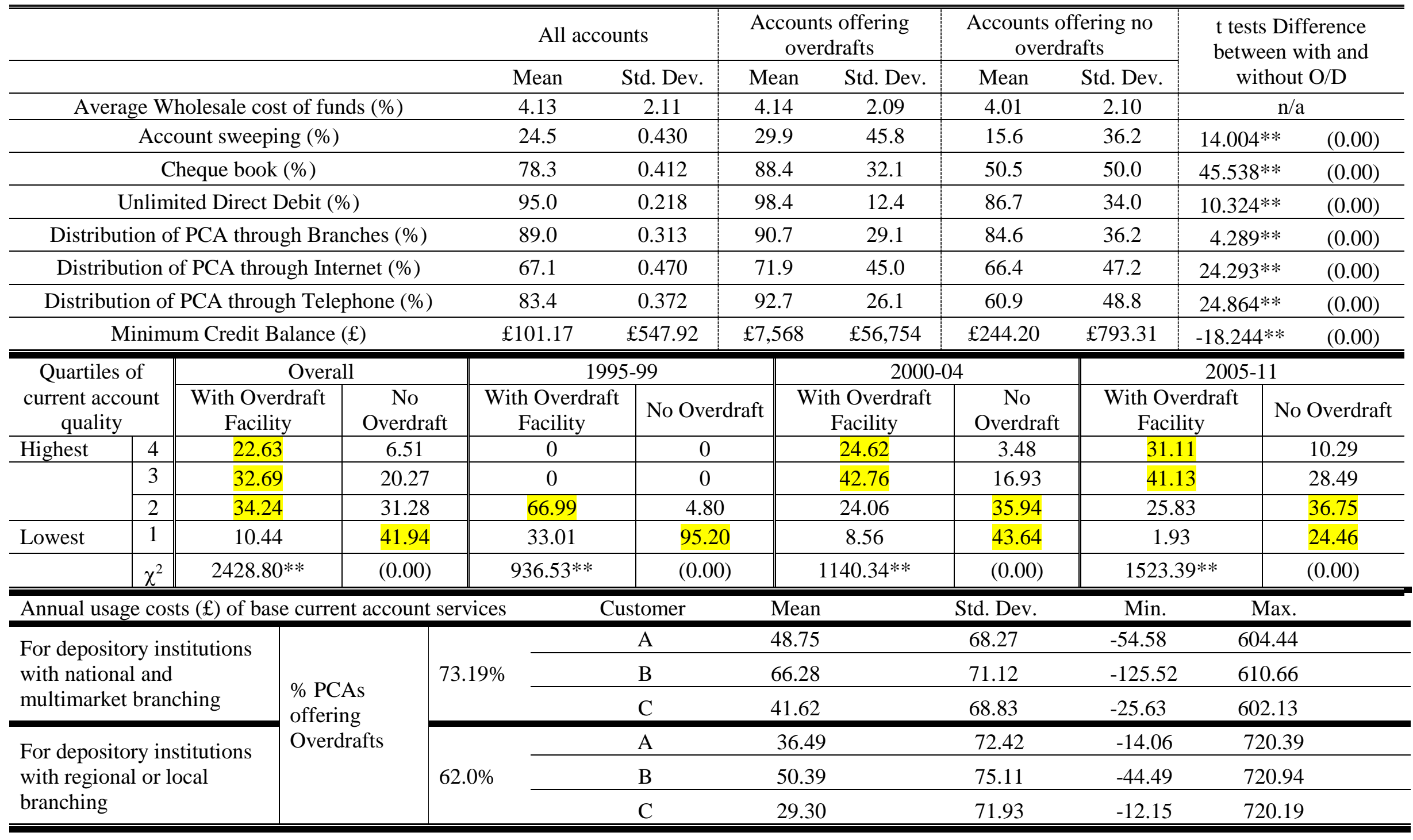


Table 6: Regression Results - Effect of offering an overdraft services on the cost of using current account base services

\begin{tabular}{|c|c|c|c|c|c|c|}
\hline \multirow{2}{*}{$\begin{array}{l}\text { Variable } \\
\text { Constant }\end{array}$} & \multicolumn{2}{|c|}{$\begin{array}{c}\text { SUR Estimates } \\
\text { Customer A }\end{array}$} & \multicolumn{2}{|c|}{$\begin{array}{c}\text { SUR Estimates } \\
\text { Customer B }\end{array}$} & \multicolumn{2}{|c|}{$\begin{array}{c}\text { SUR Estimates } \\
\text { Customer C }\end{array}$} \\
\hline & 30.77 & $(12.16)^{* *}$ & 15.53 & $(5.53) * *$ & 33.32 & $(13.48) * *$ \\
\hline Overdraft Facility & 45.22 & $(32.84)^{* *}$ & 41.62 & $(28.68) * *$ & 46.68 & $(34.00)^{* *}$ \\
\hline Base Rate & -4.62 & $(-11.72)^{* * *}$ & -0.07 & $(-0.17)$ & -6.50 & $(-16.52)^{* * *}$ \\
\hline Account Sweeping & 3.09 & $(2.35)^{* * *}$ & 4.15 & $(3.00)^{* * *}$ & 3.48 & $(2.65)^{* *}$ \\
\hline Cheque Book & -23.16 & $(-14.07)^{* *}$ & -25.49 & $(-14.80)^{* *}$ & -23.30 & $(-14.20) * *$ \\
\hline Direct Debit & -11.44 & $(-8.60) * *$ & -5.50 & $(-3.55) * *$ & -11.44 & $(-8.83) * *$ \\
\hline PCA Branch & 20.45 & $(15.00)^{* *}$ & 27.64 & $(16.63) * *$ & 17.63 & $(13.80) * *$ \\
\hline PCA Internet & 0.57 & $(0.45)$ & 2.61 & $(1.87)^{*}$ & 1.21 & $(0.97)$ \\
\hline PCA Telephone & 15.55 & $(11.17)^{* *}$ & 20.97 & $(14.07) * *$ & 14.11 & $(10.19)^{* * *}$ \\
\hline Credit Balance & 0.018 & $(8.81)^{* * *}$ & 0.018 & $(9.05)^{* *}$ & 0.018 & $(8.79)^{* * *}$ \\
\hline $\mathrm{a}_{\mathrm{i}}$ & & $(0.00)$ & & $(0.00)$ & & $.00)$ \\
\hline$b_{t}$ & & $(0.00)$ & & $(0.00)$ & & $.00)$ \\
\hline $\mathrm{SE}$ & & 64.48 & & 68.15 & & 3.94 \\
\hline$\overline{\mathrm{R}^{2}}$ & & 0.13 & & 0.11 & & .16 \\
\hline Observations & & 16676 & & 16676 & & 676 \\
\hline
\end{tabular}

Notes: SE represents the standard error of the panel estimator. $a_{i}$ and $b_{t}$ are the fixed and time effects. The (.) are p values, (.) are t statistics, ** and * indicates significant at the 5 and $10 \%$ level respectively. 
Appendix: The parent firms supplying personal current accounts used in the study.

\begin{tabular}{|c|c|c|c|}
\hline Abbey National* & Charterhouse Bank & Julian Hodge Bank & Santander* \\
\hline AIB & Chase & KBL & Schroder \\
\hline $\begin{array}{c}\text { Airdrie Savings } \\
\text { Bank }\end{array}$ & $\begin{array}{l}\text { Chelsea Building } \\
\text { Society }\end{array}$ & Kleinwort Benson & State Bank of India \\
\hline $\begin{array}{l}\text { Alliance and } \\
\text { Leicester* }\end{array}$ & Citibank & $\begin{array}{c}\text { Laiki Bank/Marfin } \\
\text { Laiki Bank }\end{array}$ & Sun Life of Canada \\
\hline $\begin{array}{l}\text { American } \\
\text { Express }\end{array}$ & Co-operative* & $\begin{array}{l}\text { Leeds and Holbeck } \\
\text { Building Society }\end{array}$ & Tridos Bank \\
\hline $\begin{array}{c}\text { Arbuthnot } \\
\text { Banking Group } \\
\end{array}$ & $\begin{array}{c}\text { Coventry Building } \\
\text { Society }\end{array}$ & $\begin{array}{l}\text { Leopold Joseph \& } \\
\text { Sons Ltd } \\
\end{array}$ & TSB* \\
\hline Bank of China & Cumberland & $\begin{array}{c}\text { Liverpool Victoria } \\
\text { Friendly Society }\end{array}$ & Turkish Bank \\
\hline Bank of Cyprus & Danske Bank & Lloyds* & Weatherbys \\
\hline Bank of Ireland & Dao Heng Bank & $\begin{array}{c}\text { Manchester } \\
\text { Building Society }\end{array}$ & $\begin{array}{c}\text { Wesleyan } \\
\text { Assurance Society }\end{array}$ \\
\hline $\begin{array}{l}\text { Bank of } \\
\text { Scotland }\end{array}$ & Dresdner Benson & Metro Bank & Western Trust \\
\hline $\begin{array}{c}\text { Banque } \\
\text { d'Escompte }\end{array}$ & $\begin{array}{c}\text { Fleming Premier } \\
\text { Banking }\end{array}$ & $\begin{array}{c}\text { National Australia } \\
\text { Bank* }\end{array}$ & $\begin{array}{c}\text { Whiteaway } \\
\text { Laidlaw Bank }\end{array}$ \\
\hline Barclays* & Halifax* & $\begin{array}{c}\text { Nationwide } \\
\text { Building Society* }\end{array}$ & Woolwich* \\
\hline Bristol and West & HBOS* & Natwest & $\begin{array}{c}\text { Yorkshire Building } \\
\text { Society }\end{array}$ \\
\hline Britannia & $\begin{array}{l}\text { HFC Finance } \\
\text { (Household } \\
\text { International) } \\
\end{array}$ & Northern Rock* & $\begin{array}{l}\text { Zurich Financial } \\
\text { Services Group }\end{array}$ \\
\hline $\begin{array}{c}\text { Butterfield } \\
\text { Private Bank }\end{array}$ & Hoare and Co & $\begin{array}{c}\text { Norwich and } \\
\text { Peterborough } \\
\text { Building Society }\end{array}$ & \\
\hline $\begin{array}{c}\text { Caledonian } \\
\text { Building Society }\end{array}$ & $\mathrm{HSBC}^{*}$ & $\begin{array}{l}\text { Portman Building } \\
\text { Society }\end{array}$ & \\
\hline $\begin{array}{c}\text { Cater Allen } \\
\text { Private Bank }\end{array}$ & Investec bank & $\begin{array}{l}\text { Royal Bank of } \\
\text { Scotland* }\end{array}$ & \\
\hline
\end{tabular}


${ }^{\mathrm{i}}$ The personal current account or checking account market is characterised by the use of different terminology internationally due to distinct laws, regulations and traditions as to how retail banking business is undertaken. As the subject of the paper is the UK, terminology from the UK is employed employing terms widely used in this nation and employed in law, regulation and government reporting. For example a personal current account (PCA) is a term used to describe a bank account offering payment services, such as direct debits and credits, standing orders and other forms of payment, deposit services and in many cases an optional overdraft facility. The term personal current account has long been used in nations with a UK banking heritage and refers to bank accounts similar to 'checking accounts', a term more widely used in North America. Other UK terms employed in this study include 'instant access deposit' - this is a deposit account offered by financial intermediary for the deposit of funds which may be accessed without prior notice being given to the bank. These accounts are also termed sight deposits in some other nations. Packaged or access fees are the fees payable for accessing some personal current accounts. Authorised and unauthorised overdrafts is borrowing undertaken through the personal current account with and without prior agreement of the provider. Throughout the study we refer to the deposit and payment services provided within a personal current account as a base good and an overdraft facility as an add-on service which is provided through an overdraft aftermarket. ii Many other academics have also reported the presence of a distributional cross-subsidy in personal current or checking account markets. For example Campbell et al (2010) stated "consumers may choose a bank account with "free" checking, underestimating the extent to which they will pay penalty fees for overdrawing their accounts in the future. Such lack of self-knowledge leads to several problems. First, naïve consumers may purchase too many bank services because they underestimate the total cost to them. Second, banks compete away the excess profits they obtain through overdraft fees by keeping base charges low on checking accounts. This implies that naïve consumers cross-subsidize sophisticated consumers who don't overdraw their accounts.' (p.11). Policy reports have also reported personal current account penalty fees are not equally shared between customers. For example in the Australian context overdraft costs 'are disproportionately borne by those who can least afford to pay them, namely low income customers' (Rich 2004, p.11). Cross-subsidies have also be reported in other financial services markets. For example Schuh et al (2010) examine the presence of cross-subsidies in US credit card markets.

iii While discussion of the wider functions of the payments system is beyond the scope of this study, reviews are provided for the UK and Nordic nations by Milne (2006) and for the USA by Gerdes (2008). iv The data provided by Moneyfacts PLC is also used by financial and competition law regulators in the UK including the Bank of England and the Competition Commission in addition to providing a key source of comparison for many UK based financial institutions and financial advisors. This data has been provided since 1989, yet has only been provided in a consistent format for personal current accounts since 1995 .

${ }^{v}$ Packaged accounts are personal current accounts which are provided on payment of a fee. It is common for these personal current accounts to offer a range of different payment services, be distributed through an assortment of channels and offer a range of additional services such as travel or identity insurance.

${ }^{v i}$ Basic bank accounts are personal current accounts developed and issued in the UK to combat financial exclusion amongst certain and often less wealthy individuals. These accounts offer limited payment services and often do not provide access to overdraft services.

vii For example, some large North American institutions, such as Sun Bank or Citi operate in the UK on a relatively small scale. 
viii These markets are also substantial in other nations. For the USA, Parrish and Frank (2011) reported consumers paid $\$ 23.7 \mathrm{bn}$ in overdraft fees in 2008; an increase of 35 per cent since 2006 (\$17.5bn) suggesting multiple concerns arising in this market.

ix These concerns are international in scope. For example in the USA the Consumer Financial Protection Bureau (2013, p.18) reported '.... consumers from potentially vulnerable groups may shoulder a disproportionate share of NSF (non-sufficient funds) and overdraft fees and checking account costs'. The Australian Senate report on competition in retail banking (2011, paragraph 4.69) also reported contingent bank fees from overdraft use may fall disproportionately on the poor and 'poorer customers who do pay fees subsidise their wealthier counterparts on a per transaction basis'.

$x$ Full details of the Lending Code are available from the Lending Standards Board (www.lendingstandardsboard.org.uk/). 